\title{
Spatial Data Infrastructure in Natural Disaster Management
}

\author{
Slobodanka Ključanin*, Milan Rezo, Suada Džebo, Emina Hadžić
}

\begin{abstract}
Natural disasters that cause tremendous material harm and threaten human lives, infrastructure, and economic and social activities become more frequent. While most material and human casualties are the effects of sudden and brief natural disasters, it is not possible to disregard long-term disasters, most frequently triggered by climate change. Damage from long-term disasters is quite significant and hampers the sustainability of the economy and life in densely populated cities. Following climate change, it is concluded that special attention should be paid to coastal cities, cities along rivers and the potential risks of possible disasters should be reduced before they materialize. The reduction of disaster risk is an endeavor involving various professional fields, viewpoints, and stakeholders. An integrated approach that brings together all the necessary elements is therefore required. The planning for protection against natural disasters and in the very moments when it occurs, it is necessary to quickly obtain reliable data to coordinate activities in the field well. However, there are problems in the field with the availability, access, and spatial data use. In this sense, the Spatial Data Infrastructure (SDI) can provide an appropriate framework for sharing spatial data through the cooperation of administration, public, and private institutions and citizens.
\end{abstract}

Keywords: natural disasters; spatial data; spatial data infrastructure

\section{INTRODUCTION}

The term natural disasters require a precise definition, as there are some terminologies associated with this term. In large part of the professional literature, one can find claims that natural disasters do not exist. Only natural hazards can turn into disasters due to the significant exposure of people, animals, and material goods. However, the fact that we deal only with those dangers that turn into a catastrophe allows us to deal with them to reduce them and prevent them, to reduce the risks. In this context, the hazard is a phenomenon that can damage property and other public resources and interrupt economic and social operations and cause injury or loss of human life and deterioration of the environment ([1,2]). A natural hazard is the result of earthquakes, landslides, volcanic eruptions, floods, or storms in the form of geophysical, geological, or hydrometeorological activity [3]. A natural hazard can escalate into a natural disaster (see Fig. 1). A natural disaster results from exposure to risky elements and the community's inability to cope with the situation ([4, 2]).

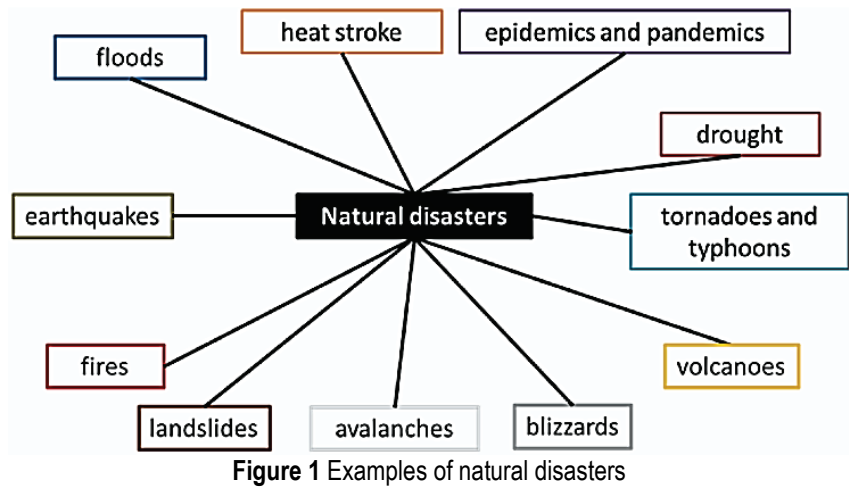

The degree of risk of disasters in a particular place is a function of hazard, vulnerability, and resilience. Vulnerability is a state of possible danger-related harm or damage. Resilience is a condition in which, by using its own tools to recover its pre-examined circumstances and functions, a structure or society undergoing a catastrophe can survive its impacts. However, it is not straightforward to measure resistance; other approaches should therefore be used in economic or systemic terms to calculate risk [5]. In the Methodology for assessing Bosnia and Herzegovina's threat from natural or other disasters [6], the terminology used for vulnerability, its assessment, exposure to gambling, and the risk of the natural disaster. Vulnerability refers to specific physical, social, and economic factors or environmental processes that raise a community's vulnerability to a particular hazard. Vulnerability assessment is a continuous assessment of the presence and impact of risk elements on people's safety, their property (including domestic animals), and the environment. Gambling exposure means the number, types, quality, and monetary value of various types of material goods or infrastructure and life that may be subject to undesirable hazards that may cause physical injury. Exposure is the only quantification of the risk in the identified hazard zone. The hazard of a natural catastrophe is the likelihood of adverse effects or anticipated damages (dead, destroyed buildings, families, interruption of economic development, or environmental destruction) resulting from encounters between hazards triggered by natural or human activities and circumstances of vulnerability.

In battling the challenge of climate change, optimum resource allocation is very important. In this way, a greater understanding of risk makes for a proactive rather than a reactive strategy. As an important part of asset management, which is included in ISO 55001: 2014, risk recognition and management were recognized. For risk identification and prevention, the main steps are:

- Hazard identification,

- Risk analysis, and

- Risk evaluation [7].

Geospatial data can be beneficial and significant in decision-making at all stages of risk management. Initially, 
geospatial data were mostly used to respond to a disaster adequately, but later their role extended to the entire risk management decision-making cycle. Avoiding major disasters begins with identifying hazards in a particular area. In addition, an assessment of the vulnerability of people, facilities, and property should be made. Disaster risk management begins with creating a database of geospatial data, inventory, overlapping layers, risk analysis, costs, scenarios, probabilities, sensitivities, decision matrices, spatial statistics correlations, and many other spatial analyzes and algorithms. After defining the most vulnerable areas, the mitigation process begins. The next step is to prepare a scenario in case of natural hazard. Geospatial databases can help identify shelters, alternative evacuation routes outside the danger zone, hospital capacity, etc. It is also possible to estimate the amount of food, water, and medicine for a particular area. With geospatial data, analyzes are performed during a disaster to perform damage assessment very quickly. Other activities where GIS is beneficial in the event of a disaster are: determining the area for evacuation, delivery of various aids, identification of damaged or blocked roads, planning routes for emergency supplies, identification of locations, people, equipment, shelters, and other resources needed for disaster management. The post-disaster phase includes recovery and reconstruction. It is a process of restoring vital qualities and rebuilding the entire community. Disaster management includes a set of activities that start with the mitigation consequences of the disaster, organizing emergency activities (search and rescue the living things, firefighting) and help in recovery from natural disasters. Recovery from natural disasters includes the physical reconstruction of facilities and the restoration of quality of life after a disaster. Quality spatial information is a fundamental condition for efficient disaster management. However, current studies show significant problems with managing spatial information (i.e., data) needed for disaster management concerning data collection, sharing, access, and use [8].

There are problems with spatial data management that become even more serious in the disaster response phase. Action during natural disasters is dynamic, and decisionmakers must have the latest spatial data to react adequately and quickly. Any delay in the collection, access, use, and exchange of data is detrimental to the quality of decisionmaking and the quality of disaster response. With this in mind, appropriate frameworks and technologies should be used to address the spatial data issues necessary for disaster management. To adequately respond to a natural disaster, it is necessary to integrate a multitude of data sets, for which many institutions are responsible. Spatial data infrastructure (SDI) can solve the problem of accessibility by creating a framework for their sharing [9].

Simultaneously, institutions involved in the community for disaster management, as the SDI participants, have a legal obligation to collect and maintain the data sets for which they are competent. Assuming that each institution does its job conscientiously then, up-to-date spatial data sets can be expected to be available to decision-makers in the event of natural disasters.

\section{THE ROLE OF SPATIAL DATA INFRASTRUCTURE IN DISASTER MANAGEMENT}

\subsection{INfrastructure for Spatial InfoRmation in Europe (INSPIRE)}

INSPIRE (INfrastructure for Spatial InfoRmation in Europe) is an initiative launched to establish a European Spatial Data Infrastructure (ESDI) [10]. This initiative calls on the Member States of the European Union (EU) to publish their geographic data on the geoportal and gradually harmonize it. To support the integration of national infrastructures into INSPIRE, members should allow access to their infrastructure through INSPIRE-geoportals and other access points. INSPIRE is based on spatial data infrastructures established and implemented by the EU Member States. It covers 34 topics related to space data (Tab. 1). The Directive entered into force on 15 May 2007 and is planned to be implemented in phases, with full implementation by $2021([11,12])$.

Table 1 Three groups spatial data topics of INSPIRE Directive [11]

\begin{tabular}{|c|c|c|}
\hline Annex 1 & Annex 2 & Annex 3 \\
\hline $\begin{array}{l}\text { - Addresses } \\
\text { - Cadastral } \\
\text { - Parcels } \\
\text { - Geographical Grid } \\
\text { Systems } \\
\text { - Hydrography } \\
\text { - Transport } \\
\text { Networks } \\
\text { - Administrative } \\
\text { Units } \\
\text { - Coordinate } \\
\text { Reference Systems } \\
\text { - Geographical } \\
\text { Names } \\
\text { - Protected Sites }\end{array}$ & $\begin{array}{l}\text { - Elevation } \\
\text { - Land Cover } \\
\text { - Geology } \\
\text { - Orthoimagery }\end{array}$ & $\begin{array}{l}\text { - Agricultural and } \\
\text { Aquaculture Facilities } \\
\text { - } \text { Bio-geographical Regions } \\
\text { - } \text { Euildings } \\
\text { - Energy Resources } \\
\text { Environmental Monitoring } \\
\text { - Hacilities } \\
\text { - Humitats and Biotopes } \\
\text { - } \text { Meteorological and Safety } \\
\text { Geographical Features } \\
\text { - Mineral Resources } \\
\text { - Oceanographic } \\
\text { Geographical Features } \\
\text { - Natural Risk Zones } \\
\text { - Population Distribution and } \\
\text { Demographics } \\
\text { - Production and Industrial } \\
\text { Facilities } \\
\text { - Sea Regions } \\
\text { - Statistical Units } \\
\text { - Soil } \\
\text { - Species Distribution } \\
\text { - Land Use } \\
\text { - Utility and Governmental } \\
\text { Service }\end{array}$ \\
\hline
\end{tabular}

The main principles of the INSPIRE Directive can be implement $([13,14])$ :

1) Data shall be collected once and maintained at the level at which it is most effective.

2) Allow spatial data from different sources to be combined and shared among users and applications.

3) Spatial data collected at one level of the management structure can be shared at all levels.

4) Spatial data should be available under conditions that do not limit their extensive use.

5) Enabling easy detection of the required spatial data, knowing the conditions of their use.

6) Spatial data should be easy to understand, interpret, and should be visualized in a user-friendly manner. 


\subsection{Spatial Data Infrastructure (SDI)}

The Spatial Data Infrastructure (SDI) is a set of technologies, measures, standards, implementing rules, services, human capacity, and other factors that enable the effective aggregation, management, and maintenance of spatial data sharing to meet national and European needs (Fig. 2 and 3).

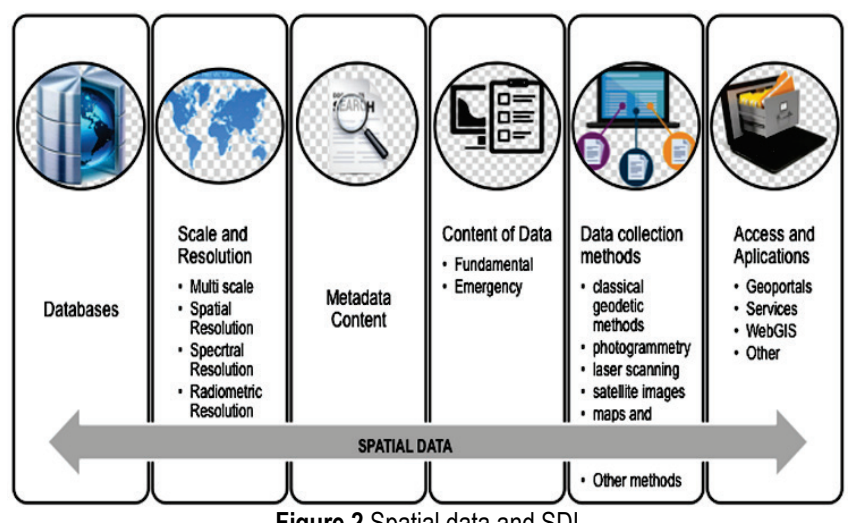

Figure 2 Spatial data and SDI

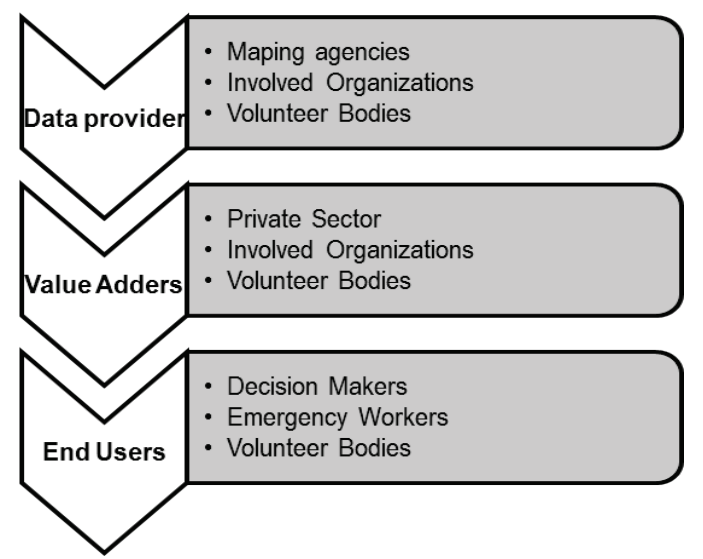

Figure 3 Scheme of connection of human capacities of different specialties in SDI

The purpose of establishing SDI is to streamline spatial data collection and standardize them to be networked and used well. Linking different spatial data types and their interoperability will enable users to conduct complex searches and analyze, and connect to spaces.

Thus, the preconditions for modern and efficient management of space and spatial resources will be realized, which directly stimulates and increases economic growth $([15,12])$.

In general, the Spatial Data Infrastructure establishment implies creating an environment that will enable a wide range of users to access, retrieve, and securely share spatial data. By implementing SDI, users save resources, time, and effort around collecting new datasets by avoiding duplication of costs related to data production and maintenance and have the ability to integrate their own data with other datasets. SDI implies integrating spatial data of different institutions and organizations, which is based on cooperation and partnership. Using SDI, effective natural and other disaster management model can be developed (Fig. 4).

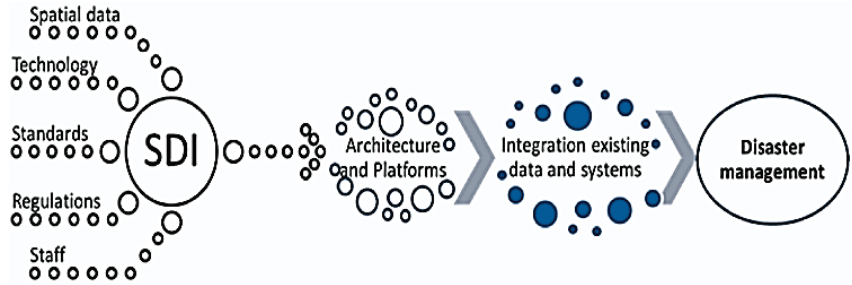

Figure 4 Relationship between SDI and Disaster management

Bosnia and Herzegovina (B\&H) is not a member of the European Union, and the implementation of the INSPIRE Directive is not binding on it. However, the importance of INSPIRE principles for the advancement of the economy and other areas of society as a whole is recognized. It has established two SDI Geoportals (for Federation B\&H and Republika Srpska) and services through sharing data with SDI subjects (only a few services and data sets). Accordingly, the Government of Federation B\&H has adopted the Regulation on the SDI Federation B\&H, appointed the Council members, and adopted the SDI Strategy. The Federal Administration for Geodetic and Property Affairs has appointed as the contact point of the SDI in Federation B\&H.

\subsection{Spatial Data Sharing}

It is necessary to create an appropriate legal and business framework with the mandatory application of technical rules to create an efficient environment (virtual and real) for sharing spatial data between different institutions. There are different spatial data sharing models, which increase the availability and access to data of users of public institutions (state, federal, cantonal, municipal, and other institutions). No matter which model of sharing spatial data is adopted, it is necessary to previously implement legal, organizational, semantic, and technical interoperability. Natural disaster management involves the easy discovery, access, and use of spatial and non-spatial data defined by crucial data sets. For each spatial data set, which is considered crucial, defining the legal framework and data management procedures is necessary. That includes metadata about the frequency: of data updates, data set sources and data quality assurance. Data sharing is enabled through a web service. Thus, using data is simplified, and available time in protecting against natural disasters is spent more efficiently.

\section{DEFINING KEY DATA SETS FOR NATURAL DISASTER MANAGEMENT}

Unfortunately, there is still no appropriate database model on natural and other disasters in Bosnia and Herzegovina. Therefore, a proposal of key data sets for natural disaster management, based on INSPIRE topics, is proposed here. According [16] there are four group key datasets for natural disaster management:

1) Hazard

2) Vulnerability 
3) Risk $^{1}$

4) $\operatorname{Exposed}^{2}[16]$.

\begin{tabular}{|c|c|c|}
\hline Group & Key Datasets & INSPIRE topic \\
\hline \multirow{12}{*}{ Hazard } & Watershed boundaries & Hydrography \\
\hline & Water bodies & Hydrography \\
\hline & Soil type & $\begin{array}{l}\text { Soil } \\
\text { Natural Risk Zone }\end{array}$ \\
\hline & Flood hazard maps & $\begin{array}{l}\text { Natural Risk Zone; } \\
\text { Hydrography }\end{array}$ \\
\hline & Meteorological gauge data & $\begin{array}{l}\text { Meteorological Geographical } \\
\text { Features } \\
\text { Hydrography }\end{array}$ \\
\hline & Flood protection measures & $\begin{array}{l}\text { Hydrography - Hydro } \\
\text { Physical Waters } \\
\text { Natural risk zone }\end{array}$ \\
\hline & Seismic hazard map & $\begin{array}{l}\text { Meteorological Geographical } \\
\text { Features } \\
\text { Natural risk zone } \\
\text { Geology }\end{array}$ \\
\hline & Site conditions map & Geology, Soil \\
\hline & Wind & $\begin{array}{l}\text { Meteorological Geographical } \\
\text { Features } \\
\text { Natural risk zone }\end{array}$ \\
\hline & $\begin{array}{l}\text { Historical records of } \\
\text { significant natural hazard } \\
\text { events in the country }\end{array}$ & Natural Risk Zone \\
\hline & $\begin{array}{l}\text { Environmental hazardous } \\
\text { activities }\end{array}$ & Natural risk zone \\
\hline & Contaminated sites & Natural risk zone \\
\hline \multirow{11}{*}{ Exposed } & Land Use & Land Use \\
\hline & Population & $\begin{array}{l}\text { Population Distribution and } \\
\text { Demographics }\end{array}$ \\
\hline & Economic activities & $\begin{array}{l}\text { Production and Industrial } \\
\text { Facilities }\end{array}$ \\
\hline & Company registers & $\begin{array}{l}\text { Production and Industrial } \\
\text { Facilities }\end{array}$ \\
\hline & Buildings & Buildings \\
\hline & Agricultural production & $\begin{array}{l}\text { Agricultural and Aquaculture } \\
\text { Facilities }\end{array}$ \\
\hline & Critical infrastructures & $\begin{array}{l}\text { Transport Network } \\
\text { Utility and Governmental } \\
\text { Service } \\
\text { Hydrography - 'Hydro - } \\
\text { Physical Waters' } \\
\text { Buildings } \\
\end{array}$ \\
\hline & $\begin{array}{l}\text { Expected growth of } \\
\text { population density }\end{array}$ & No topic \\
\hline & Expected growth of GDP & No topic \\
\hline & Cultural Heritage & Buildings \\
\hline & Environment & Protected sites \\
\hline \multirow{2}{*}{ Vulnerability } & $\begin{array}{l}\text { Direct Economic } \\
\text { vulnerability }\end{array}$ & Natural risk zone \\
\hline & $\begin{array}{l}\text { Indirect Economic } \\
\text { vulnerability }\end{array}$ & Natural risk zone \\
\hline \multirow{3}{*}{ Risk } & $\begin{array}{l}\text { Risk indicators from } \\
\text { previous studies }\end{array}$ & Natural risk zone \\
\hline & Risk assessment & Natural risk zone \\
\hline & $\begin{array}{l}\text { Historical Impacts on } \\
\text { exposure }\end{array}$ & Natural risk zone \\
\hline
\end{tabular}

To these groups should be added a group named basic data sets, which are not directly related to natural disasters, which include:
- Reference coordinate system,

- Topographic bases (maps, digital orthophotos, satellite images, laser scanning of the terrain),

- Digital terrain model,

- Administrative units,

- Geographical names and

- Landcover.

The proposal of crucial data sets according to the division of groups and their coverage of INSPIRE topics are presented in Tab. 2.

Based on the defined key data sets and INSPIRE specifications for the mentioned INSPIRE topic, it is possible to create an appropriate data model that will be used for planning protection against natural disasters and effective action during natural disasters. Data from crucial spatial data sets should be described on the SDI Geoportal, and data access provided through a web service with previously signed spatial data sharing agreements and data use agreements.

\section{EXAMPLE OF DETERMINING SECTIONS OF MAJOR ROADS EXPOSED TO FLOOD RISK}

This paragraph proposes a technique for the development of a GIS browser. It offers an example of a thematic map for identifying critical sections of the Federation of Bosnia and Herzegovina's major roads exposed to natural flood disasters that can be used for flood risk management. Integration of collected data into free QGIS software, allowing spatial data to be analysed and visualized.

Three data sets are grouped into layers loaded into GIS software, namely (Fig. 5):

1) Administrative boundaries with layers:

2) Road network

3) Rivers and flood lines.

The subject of research in this example will be major road sections in the Sava River Basin.

The rivers in Federation $\mathrm{B} \& \mathrm{H}$ that belong to the Sava River's catchment area are Una, Vrbas, Bosna, and Drina.

The layers of hazard and the layers of risk elements need to be identified at the beginning. The layer of "Sava Flood $100 \mathrm{Y}$ " is classified as a hazard layer, while the layer of the "Main Road Network" is defined as a layer representing elements exposed to such hazards (Fig. 5).

As the road network is of the same (major) category, there was no need to classify the road network, while the flood lines were classified into different water-level grades, as follows:

- Low risk: 0 - $1000 \mathrm{~mm}$

- Medium risk: $1001-2000 \mathrm{~mm}$

- High risk: > $2000 \mathrm{~mm}$.

\footnotetext{
${ }^{1}$ Risk is the combination of the consequences of an event (hazard) and the associated likelihood/probability of its occurrence [17].
} 


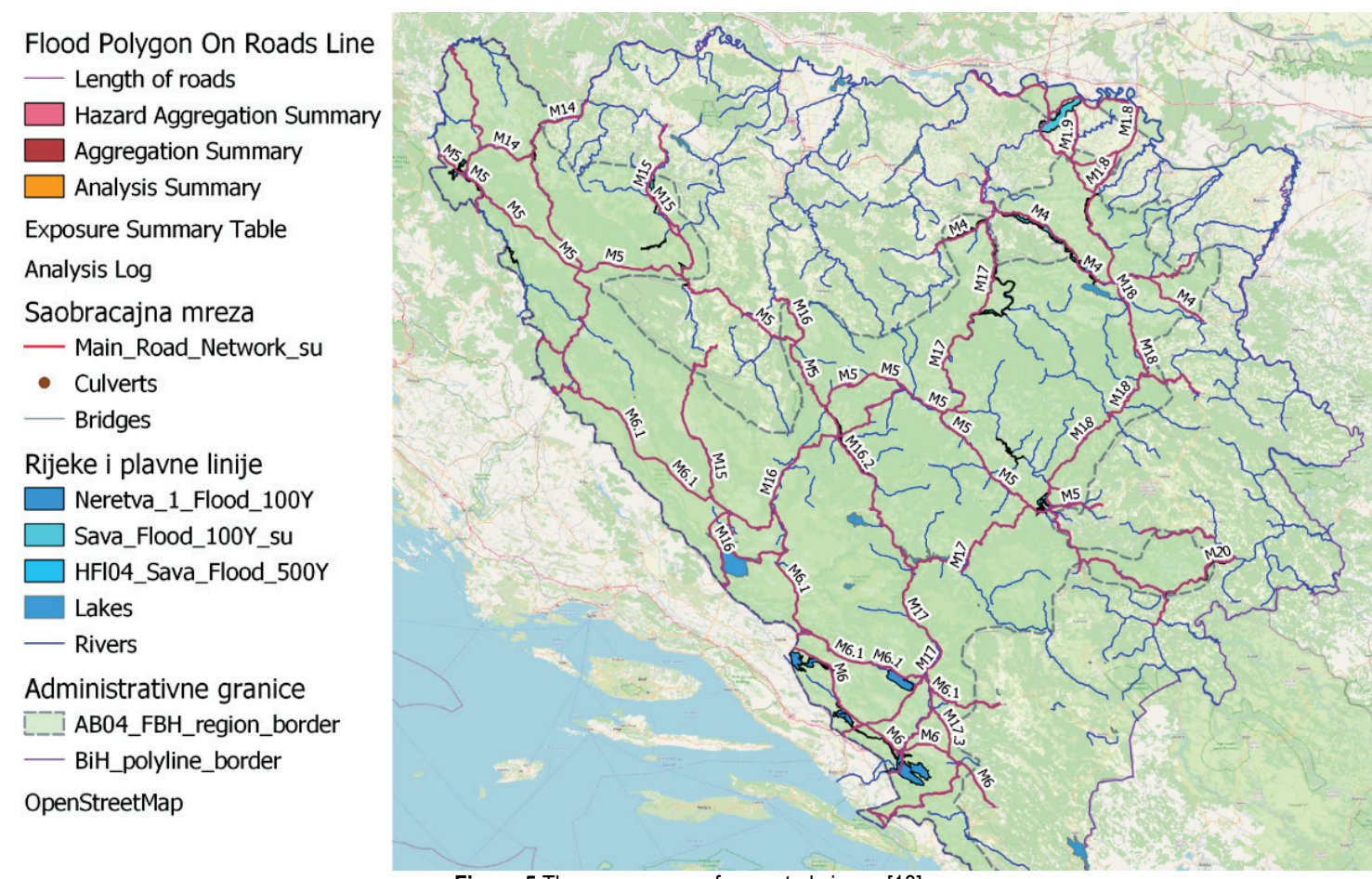

Figure 5 The appearance of a created viewer [18]

The program add-on "InaSAFE" has been used to determine the critical road sections. These road sections that overlap with the Sava River Basin flood lines (for 100 years return period). A thematic flood risk management map and the results of the data analysis are displayed in numerical and graphical form (Figs. 6, 7, 8, and 9).

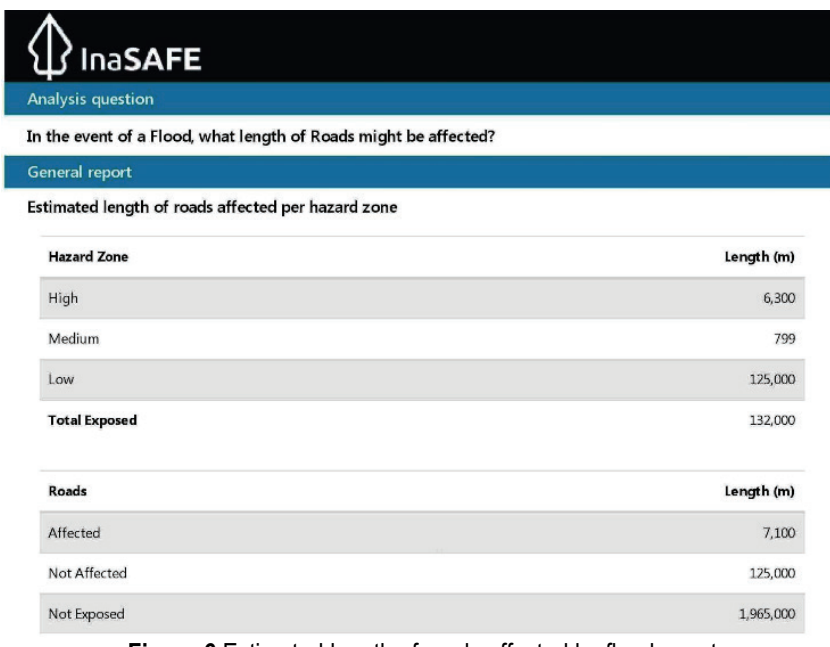

Figure 6 Estimated length of roads affected by flood event

It can be found (Fig. 7) that the road route M4 is subject to a high flood risk of $4.7 \mathrm{~km}$ in length (Fig. 8). The M20 road exposed to medium risk in the length of $0.8 \mathrm{~km}$, while the M5 road in the length of $52.2 \mathrm{~km}$ and the M15 in the length of $45.5 \mathrm{~km}$ are the exposed to low risk.

\begin{tabular}{|c|c|c|c|c|c|c|c|}
\hline \multicolumn{8}{|c|}{$\begin{array}{l}\text { Analysis detail } \\
\text { Estimated length of roads ( } m \text { ) affected by road type }\end{array}$} \\
\hline \multirow[t]{2}{*}{ Road type } & \multicolumn{3}{|c|}{ Affected } & \multicolumn{2}{|c|}{ Not affected } & \multirow[t]{2}{*}{ Total not exposed } & \multirow[t]{2}{*}{ Tota } \\
\hline & High & Medium & Total affected & Low & Total not affected & & \\
\hline M15 & 0 & 0 & 0 & 45,500 & 45,500 & 196,000 & 242,000 \\
\hline M14.1 & 0 & 0 & 0 & 14,500 & 14,500 & 45,600 & 60,000 \\
\hline M16 & 178 & 0 & 178 & 0 & 0 & 114,000 & 114,000 \\
\hline M16.3 & 0 & 0 & 0 & 0 & 0 & 3,300 & 3,300 \\
\hline M19.2 & 0 & 0 & 0 & 0 & 0 & 28,600 & 28,600 \\
\hline M4 & 4,700 & 0 & 4,700 & 0 & 0 & 122,000 & 126,000 \\
\hline M1.8 & 789 & 0 & 789 & 0 & 0 & 70,500 & 71,300 \\
\hline M5 & 0 & 0 & 0 & 52,200 & 52,200 & 360,000 & 413,000 \\
\hline M11 & 0 & 0 & 0 & 752 & 752 & 8,500 & 9,200 \\
\hline M20 & 0 & 799 & 799 & 864 & 864 & 32,800 & 34,500 \\
\hline M16.4 & 141 & 0 & 141 & 0 & 0 & 39,000 & 39,200 \\
\hline M1.9 & 0 & 0 & 0 & 0 & 0 & 32,200 & 32,200 \\
\hline M17 & 6 & 0 & 6 & 6,400 & 6,400 & 217,000 & 223,000 \\
\hline M18 & 0 & 0 & 0 & 0 & 0 & 179,000 & 179,000 \\
\hline M16.2 & 463 & 0 & 463 & 0 & 0 & 69,400 & 69,800 \\
\hline M14.2 & 0 & 0 & 0 & 228 & 228 & 151,000 & 15,000 \\
\hline M6.1 & 0 & 0 & 0 & 0 & 0 & 160,000 & 160,000 \\
\hline M14 & 0 & 0 & 0 & 4,500 & 4,500 & 66,400 & 70,900 \\
\hline M18.1 & 0 & 0 & 0 & 0 & 0 & 46,300 & 46,300 \\
\hline M.2. & 0 & 0 & 0 & 0 & 0 & 27,000 & 27,000 \\
\hline Total & 6,300 & 799 & 7,100 & 125,000 & 125,000 & $1,965,000$ & $2,097,000$ \\
\hline
\end{tabular}

Figure 7 Estimated length of roads affected by road route 
The M4 road (the valley of the river Bosna and its tributaries Spreča) is a more densely populated area in the Federation of Bosnia and Herzegovina with the most significant industrial capacity, so often increasing watercourses and overflows result in endangering residential and commercial buildings and traffic interruption.

A thorough review of the identified road sections recommending steps at all flood risk management stages would be the next step. In all phases of the comprehensive flood risk management cycle, data read from the thematic map can be used: prevention, protection, awareness, readiness, and recovery.

\section{CONCLUSION}

Growth of the world population accompanied by urbanization and increased pressures on natural resources, and the process of land conversion in combination with natural hazards lead to increased vulnerability, both people and material goods [19]. Viewed from this angle, effective management of disasters is crucial. Effective disaster management involves managing a range of activities that begin with mitigating vulnerability and the adverse effects of disasters, increasing people's readiness to provide emergency assistance, and actively participating in disaster recovery physical reconstruction and restoring the quality of life of the community. For the effective implementation of these activities, it is necessary to have easy access to reliable spatial and other information, which needs to be integrated. Since there are many data sets whose collection and maintenance are the responsibility of various public institutions, there are significant problems in their detection and sharing. The establishment of a Spatial Data Infrastructure (SDI) creates a basic framework for sharing up-to-date spatial data accessible to the broader community and contributes to better management of natural disasters. Since Bosnia and Herzegovina tend to join the European Union, the procurement, collection, preservation, and management of IT-based geo-data sets contribute to the need for accelerated standardization and harmonization of the geodata sets with EU regulations in the INSPIRE Directive [18].

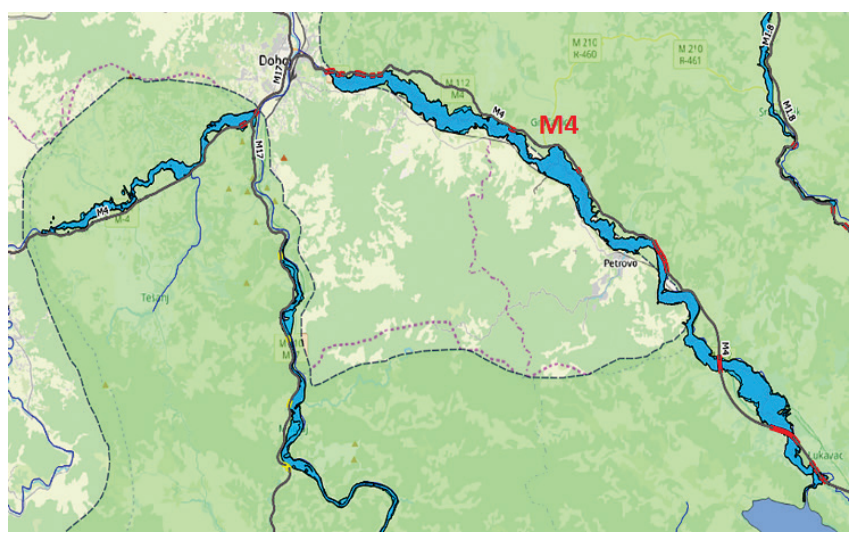

Figure 8 Endangered high-risk sections on the M4 road - the area of the city of Doboj

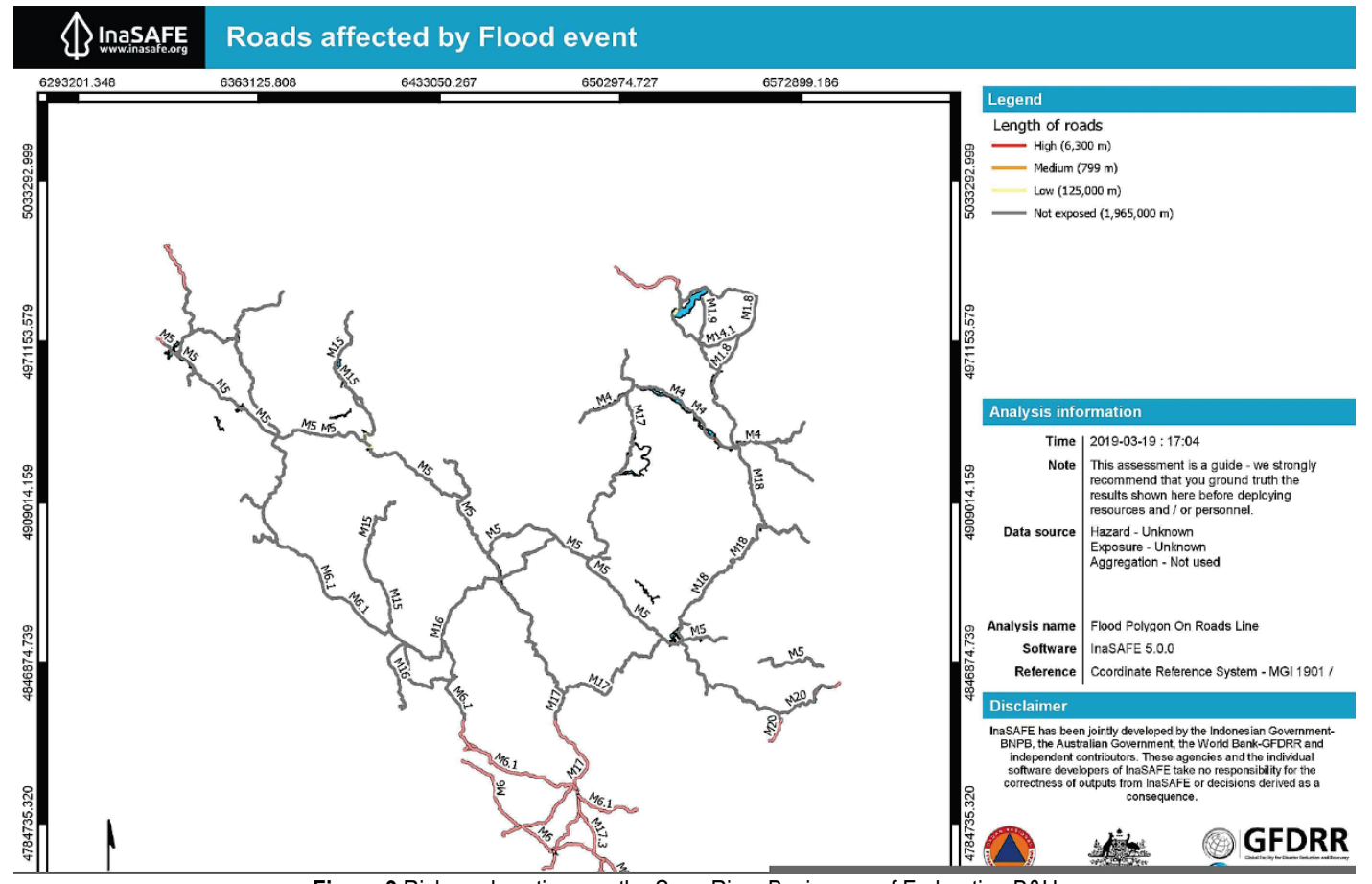

Figure 9 Risk road sections on the Sava River Basin area of Federation B\&H

\section{REFERENCES}

[1] FEMA (1997). NEHRP Guidelines for the Seismic Rehabilitation of Buildings. Report No. 273, Federal Emergency Management Agency, Washington DC.
[2] UNISDR (2009). United Nations International Strategy for Disaster Reduction. Geneva, Switzerland. https://www.uclg.org/sites/default/files/7817_unisdrterminolo gyenglish.pdf 
[3] Benson, C. \& Clay, E. (2004). Understanding the Economic and Financial Impacts of Natural Disasters. Disaster Risk Management Series, no. 4. Washington, DC: World Bank. C) World Bank. https://openknowledge.worldbank.org/handle/ 10986/15025 License: CC BY 3.0 IGO. https://doi.org/10.1596/0-8213-5685-2

[4] Misonali, R. \& McEntire, D. (2008). Rising Disasters and Their Reversal: An Identification of Vulnerability and Ways to Reduce It. Disaster Management Handbook. J. Pinkowski. Boca Raton, CRC Press. https://doi.org/10.1201/9781420058635.ch2

[5] Sutanta, H. (2012). Spatial planning support system for an integrated approach to disaster risk reduction. $P h D$ thesis, Centre for Spatial Data Infrastructures \& Land Administration, Department of Infrastructure Engineering, The University of Melbourne. https://minerva-access.unimelb.edu.au/handle/ $11343 / 37854$

[6] Službeni glasnik BiH br. 86/09 (2009). Metodologija za izradu procjene ugroženosti Bosne i Hercegovine od prirodnih ili drugih nesreća metodologiju za izradu procjene ugroženosti Bosne i Hercegovine od prirodnih ili drugih nesreća, http://www.msb.gov.ba/dokumenti/metodBOS.pdf (in Bosnian)

[7] Džebo, S., Šarić, A., Reeves, S., Ljevo, Ž., \& Hadžić, E. (2020) Flood Impact and Risk Assessment on the Road Infrastructure in Federation of Bosnia and Herzegovina. In: Advanced Technologies, Systems, and Applications IV. Proceedings of the International Symposium on Innovative and Interdisciplinary Applications of Advanced Technologies (IAT 2019). Lecture Notes in Networks and Systems, vol 83. Springer, Cham. https://doi.org/10.1007/978-3-030-24986-1_22

[8] Jain, S. \& McLean, C. (2004). A Framework for Modeling and Simulation for Emergency Response. Proceedings of the 2003 Winter Simulation Conference, New Orleans, Louisiana, USA. https://doi.org/10.6028/NIST.IR.7071

[9] Mansouriana, A., Rajabifardb, A., \& Javad Valadan Zoeja, M. (2005). SDI conceptual modeling for disaster management. ISPRS Workshop on Service and Application of Spatial Data Infrastructure, XXXVI (4/W6), Oct. 14-16, Hangzhou, China. https://www.researchgate.net/publication/228634666_SDI_co nceptual_modeling_for_disaster_management

[10] EC (2007). European Commission: DIRECTIVE 2007/2/EC of the Europian Parliament and of the Council: establishing an infrastructure for spatial information in the Community (INSPIRE), Brussels.

[11] Ključanin, S., Rossello, L., \& Traverso, S. (2019). ERRA IPA DRAM Manual and Guidelines for Data Experts. https:/www.researchgate.net/publication/339508648_ERRA_ IPA_DRAM_Manual_and_Guidelines_for_Data_Experts

[12] Ključanin, S., Poslončec-Petrić, V., \& Bačić, Ž. (2018). Osnove infrastrukture prostornih podataka. Dobra knjiga, Sarajevo. Bosna i Hercegovina. (in Bosnian)

[13] DGU (2008). Nacionalna infrastruktura prostornih podataka i INSPIRE, Državna geodetska uprava Republike Hrvatske, Zagreb. (in Croatian)

[14] Poslončec-Petrić, V. (2010). Distribucija prostornih podataka za potrebe službene kartografije Republike Hrvatske. Doktorska disertacija, Geodetski fakultet, Zagreb. (in Croatian)

[15] Poslončec-Petrić, V., Cetl, V., Babić, K. (2011). Uspostava infrastrukture prostornih podataka u Hrvatskoj. Građevinar, 63(12), 1087-1093. Retrieved from https://hrcak.srce.hr/75960 (in Croatian)
[16] https://inspire.ec.europa.eu/documents/Data Specifications/INSPIRE_DataSpecification_NZ_v3.0RC2.pdf

[17] https://ec.europa.eu/echo/files/about/COMM_PDF_ SEC_2010_1626_F_staff_working_document_en.pdf

[18] Ključanin, S., Džebo, S., Drugovac, M., \& Bilalagić, I. (2020) Use of GIS Viewer for Flood Risk Management on the Main Road Network in the Federation of Bosnia and Herzegovina. In: Advanced Technologies, Systems, and Applications IV Proceedings of the International Symposium on Innovative and Interdisciplinary Applications of Advanced Technologies (IAT 2019). Lecture Notes in Networks and Systems, vol 83. Springer, Cham. https://doi.org/10.1007/978-3-030-24986-1_21

[19] Hadžić, E., Ključanin, S., \& Milišić, H. (2018). Significance of Spatial planning and GIS technology in reducing natural disaster effects. Forth Scientific-professional Conference Security and Crisis Management - theory and practice "SeCMan2018" Proceeding, Regional association for safety and crisis management (RASEC) and S4 Global security, 139147.

\section{Authors' contacts:}

Slobodanka Ključanin, PhD, Associate Professor

(Corresponding author)

University of Bihać - Technical Faculty,

Dr. Irfana Ljubijankića b.b., 77000 Bihać, Bosnia and Herzegovina

E-mail: slobodanka63@yahoo.com

Milan Rezo, PhD, Assistant Professor

University North, University Center Varaždin,

Jurja Križanića 31b, 42000 Varaždin, Croatia

E-mail: milan.rezo@unin.hr

Suada Džebo, PhD, Assistant Professor

University of Sarajevo - Faculty of Civil Engineering,

Patriotske lige 30, 71000 Sarajevo, Bosnia and Herzegovina

E-mail: suada.dzebo.gf@gmail.com

Emina Hadžić, PhD, Full Professor

University of Sarajevo - Faculty of Civil Engineering,

Patriotske lige 30, 71000 Sarajevo, Bosnia and Herzegovina

E-mail: eminahd@gmail.com 